\title{
Ukuran Perusahan Sebagai Variabel Kontrol Dalam Determinan Struktur Modal Manufaktur
}

\author{
I Wayan Wardita*, Ni Made Gunastri, I Made Purba Astakoni dan Ida Bagus Swaputra \\ Prodi Manajemen, Sekolah Tinggi Ilmu Manajemen Handayani, Denpasar-Indonesia \\ *Corresponding email: warditayanwar@gmail.com
}

\begin{abstract}
How to cite (in APA style):
Wardita, I. W., Gunastri, N. M., Astakoni, I. M. P., \& Swaputra, I. B. (2021). Ukuran Perusahan Sebagai Variabel Kontrol Dalam Determinan Struktur Modal Manufaktur. Wacana Ekonomi (Jurnal Ekonomi, Bisnis dan Akuntansi), 20 (2), pp.144-160. https:// doi.org/10.22225/we.20.2.2021.144-160
\end{abstract}

\begin{abstract}
This study raises several objectives, namely (1) analyzing the effect of profitability on capital structure, (2) analyzing the effect of asset structure on capital structure, (3) analyzing the effect of business risk on capital structure, (4) comparing the results of the overall analysis with both control and variable variables. without the firm size control variable. The population in this study were all manufacturing companies in the cosmetics and household goods sector listed on the Indonesia Stock Exchange for the 2016-2020 period, namely seven companies. The samples in this study were taken according to predetermined criteria. Based on the provisions that have been set, a sample of five companies was selected. The data analysis technique in this study uses a regression approach where the processing uses the help of the Eviews Version 12 program, considering that the data analyzed is in the form of panel data. Based on the model test, both through the determination test and statistical $F$ test, very good results were obtained. The first hypothesis which states that profitability has a significant negative effect on capital structure has not been accepted (rejected). The second hypothesis which states that business risk has a significant negative effect on capital structure has not been accepted (rejected). The third hypothesis which states that asset structure has a significant positive effect on capital structure is acceptable. The results of the comparison involving the control variable of firm size, it can be explained that the model is better without the control variable because the results are suppressing or weakening the adopted model.
\end{abstract}

Keywords: Capital Structure; Determinants; Control Variables.

\begin{abstract}
Abstrak
Studi ini mengangkat beberapa tujuan yaitu (1) menganalisis pengaruh profitabilitas terhadap struktur modal, (2) menganalisis pengaruh struktur aktiva terhadap struktur modal,(3) menganalisis pengaruh risiko bisnis terhadap struktur modal,(4) membandingkan hasil analisis keseluruhan baik dengan veriabel kontrol maupun tanpa variabel kontrol ukuran perusahaan. Populasi dalam penelitian ini adalah seluruh perusahaan manufaktur sektor kosmetik dan barang keperluan rumah tangga yang terdaftar di Bursa Efek Indonesia periode 2016-2020 yaitu sebanyak tujuh perusahaan. Sampel dalam penelitian ini, diambil sesuai dengan kriteria yang telah ditetapkan . Berdasarkan ketentuan yang telah ditetapkan terpilih sampel sejumlah lima perusahaan. Teknik analisis data dalam penelitian menggunakan pendekatan regresi yang mana pengolahannya menggunakan bantuan program Eviews Versi 12, mengingat data yang dianalisis berbentuk data panel. Berdasarkan uji model, baik melalui uji determinasi maupun uji $\mathrm{F}$ statistik didapat hasil yang sangat baik. Hipotesis pertama yang menyatakan profitabilitas berpengaruh signifikan negatif terhadap struktur modal belum dapat diterima (ditolak). Hipotesis kedua yang menyatakan risiko bisnis berpengaruh signifikan negatif terhadap struktur modal belum dapat diterima (ditolak). Hipotesis ketiga yang menyatakan struktur aktiva berpengaruh signifikan positif terhadap struktur modal dapat diterima. Hasil perbandingan dengan melibatkan variabel kontrol ukuran perusahaan, dapat dijelaskan bahwa model lebih baik tanpa variabel kontrol karena hasilnya bersifat menekan atau melemahkan model yang diangkat.
\end{abstract}

Kata Kunci: Struktur Modal; Determinan; Variabel Kontrol.

\section{PENDAHULUAN}

Aspek keuangan dijadikan dasar dalam pengambilan suatu keputusan, karena keputusan dalam melakukan aktivitas pendanaan nantinya menentukan struktur modal perusahaan (Astakoni \& Utami, 2019). Keputusan pendanaan harus dicermati dengan baik karena merupakan keputusan dalam membiayai aktivitas dan investasi perusahaan. Keputusan akan perimbangan antara penggunaan 
hutang dan modal sendiri tersebut merupakan struktur permodalan yang nantinya akan digunakan untuk mendanai aktivitas dan investasi perusahaan. Di dalam perusahaan, keputusan mengenai struktur modal ditentukan oleh manajer keuangan. Manajer keuangan harus menghadapi suatu keberagaman pembelanjaan, yang berarti bahwa perusahaan harus memperhatikan benar dalam proporsi penggunaan hutang atau modal sebagai sumber dananya. Oleh karena itu, finance manager perlu memperhatikan berbagai faktor yang mempengaruhi struktur modal agar keuntungan tetap maksimal dengan biaya modal yang rendah. Persentase yang umum digunakan oleh perusahaan dalam menentukan struktur modalnya adalah sekitar 70\% modal berbanding 30\% hutang, namun hal ini kembali lagi kepada keputusan dan faktor lain di dalam perusahaan tersebut, baik faktor internal maupun faktor eksternal (Handayani \& Darma, 2018).

Oleh karena itu struktur modal tidak hanya dipengaruhi oleh faktor internal tapi juga tergantung pada pengaruh faktor luar perusahaan (eksternal). Penelitian yang dilakukan oleh Mahanani \& Asandimitra, (2017) mengangkat variable eksternal Exchange Rates, Inflation, GDP, Corporate Tax Rate dan variable internal corporate capital dalam mempengaruhi struktur modal. Penelitian mengenai struktur modal sudah banyak dilakukan utamanya mengangkat faktor internal perusahaan sebagai variable independent. Penelitian yang dilakukan oleh Astakoni \& Utami, (2019),Utami, (2019),Handayani \& Darma, (2018), Jalil, (2018),S \& Machali, (2017), Wardita \& Astakoni, (2018),(Thippayana, 2014),(Kaliman \& Wibowo, 2017),(Rahma, Muslim, \& Nalurita, 2019),(Joni \& Lina, 2010),(Mukhibad, Subowo, Maharin, \& Mukhtar, 2020),(Ahmed Sheikh \& Wang, 2011),(Çitak \& Ersoy, 2012),(Chen, Jiang, \& Lin, 2014),(Wiagustini \& Pertamawati, 2015), (Rahma et al., 2019),(Chen et al., 2014),(Astakoni \& Nursiani, 2020),(S \& Machali, 2017) semuanya membahas faktor internal perusahaan sebagai penentu struktur modal perusahaan manufaktur.

Profitabilitas merupakan rasio yang sangat sering digunakan oleh pemegang saham untuk menilai kinerja perusahaan. Profitabilitas juga memiliki peranan dalam pengambilan keputusan khususnya menentukan struktur modal. Profitabilitas berhubungan dengan tingkat penjualan, pengembalian investasi, maupun efektivitas penggunaan aktiva perusahaan. Profitabilitas selain menjadi perhatian bagi pemegang saham, juga menjadi perhatian bagi karyawan perusahaan yang menganggap bahwa semakin tinggi profitabilitas perusahaan, maka kesempatan untuk peningkatan kesejahteraan karyawan juga semakin besar. Penelitian mengenai kontribusi profitabilitas terhadap struktur modal pernah dilakukan oleh (I. M. P. Astakoni \& Mariani, 2018),(Thippayana, 2014), (Kaliman \& Wibowo, 2017), (Utami, 2019), (Handayani \& Darma, 2018) yang menemukan profitabilitas berpengaruh signifikan negatif terhadap struktur modal. Hasil yang berbeda didapat oleh (Astakoni \& Utami, 2019) bahwa profitabilitas memiliki pengaruh yang signifikan positif terhadap struktur modal.

Struktur aset menjadi salah satu faktor lain yang menentukan struktur modal. Struktur aset merupakan proporsi aset tetap dengan total aset perusahaan. Meningkatnya struktur asset perusahaan menandakan bahwa semakin besar kemampuan perusahaan dalam perolehan jaminan hutang jangka panjang. Ketika perusahaan memiliki komposisi aktiva tetap yang tinggi, maka akan memilih menggunakan dana eksternal sebagai sumber utama dalam kebutuhan modalnya (Handayani \& Darma, 2018). Penelitian (Astakoni \& Utami, 2019),(Utami, 2019) menunjukkan bahwa struktur aktiva berkontribusi secara negatif terhadap struktur modal. Jalil, (2018),S \& Machali, (2017) menemukan bahwa struktur aktiva berkontribusi secara positif terhadap struktur modal, sedangkan penelitian yang dilakukan oleh Handayani \& Darma, (2018) menemukan bahwa struktur aset tidak berkontribusi terhadap struktur modal.

Risiko bisnis menggambarkan bagaimana situasi yang mungkin akan dialami perusahaan di masa depan yang dapat digambarkan melalui deviasi laba operasional perusahaan. Risiko bisnis dapat meningkat ketika perusahaan menggunakan hutang dalam jumlah besar untuk memenuhi kebutuhan pendanaan. Rahma et al., (2019).Jalil, (2018),Ahmed Sheikh \& Wang, (2011) Joni \& Lina, (2010), Mukhibad et al., (2020) menyebutkan bahwa risiko bisnis tidak berkontribusi terhadap struktur modal, namun perbedaan ditemukan oleh (Wiagustini \& Pertamawati, 2015), (Handayani \& Darma, 2018),(Chen et al., 2014) bahwa risiko bisnis memiliki kontribusi signifikan positif terhadap struktur modal. Pada temuan lain hasil riset (Rahmawati, 2019) menemukan risiko bisnis tidak berpengaruh terhadap struktur modal.

Penggunaan modal yang semakin besar biasanya dikarenakan karena ukuran perusahaan yang semakin besar. Perusahaan membutuhkan dana yang lebih besar pula untuk menunjang operasionalnya karena aktivitas penjualannya juga lebih besar, yang berarti bahwa perusahaan 
tersebut dikatakan sebagai perusahaan dengan ukuran yang besar. Perusahaan yang berukuran besar lebih disukai oleh investor dan lebih besar pula kesempatan dalam memperoleh pendanaan eksternal. Penelitian yang dilakukan (Astakoni \& Utami, 2019),(I. M. P. Astakoni \& Mariani, 2018), (Thippayana, 2014),(Kaliman \& Wibowo, 2017),(Wiagustini \& Pertamawati, 2015),(Handayani \& Darma, 2018) menemukan bahwa ukuran perusahaan memiliki kontribusi signifikan positif terhadap struktur modal, sedangkan (Rahma et al., 2019) menunjukkan hasil bahwa variabel ukuran perusahaan memberikan kontribusi secara signifikan negatif terhadap struktur modal. Ukuran perusahaan lazimnya dalam suatu riset diangkat sebagai variabel independen, sedangkan dalam kesempatan kali ini disamping diangkat sebagai variabel independen juga difungsikan sebagai variabel kontrol (control variable) (Carlson \& Wu, 2012),(Atinc, Simmering, \& Kroll, 2012).Adanya beberapa perbedaan hasil penelitian dari beberapa peneliti tersebut di atas terhadap struktur modal, bisa disebabkan oleh alat ukur (proksi) variabel dependen maupun independen yang digunakan, perbedaan dimensi data yang digunakan (time series, cross_sexion ataupun data panel) , juga perbedaan dalam alat bantu teknik analisis yang digunakan.

Dalam studi kali ini ingin kembali dikaji mengenai faktor-faktor yang mempengaruhi struktur modal pada perusahaan manufaktur khususnya perusahaan kosmetik dan barang keperluan rumah tangga yang terdaftar di Bursa Efek Indonesia.Penelitian ini merupakan reflikasi dari beberapa riset sebelumnya dan menindaklanjuti keterbatasan dari hasil riset yang sudah pernah dilakukan. Riset yang dilakukan oleh Handayani \& Darma, (2018) mengangkat firm size, business risk, assets structure dan profitability sebagai factor penentu capital structure, dimana profitabilitas diperlakukan juga sebagai variable intervening dengan pendekatan analisis jalur.Studi yang dilakukan oleh Utami, (2019) di Bursa Efek Indonesia mengangkat model data panel dengan menampilkan variable independent asset structure, profitability, asset growth,company size dan business risk sebagai faktor penentu struktur modal. Pada penelitian kali ini diangkat kembali model regresi dengan pendekatan data panel dengan variable independen yaitu profitabilitas, struktur aktiva, risiko bisnis dan variabel ukuran perusahaan sebagai variable kontrol dalam mempengaruhi struktur modal perusahaan kosmetik dan barang keperluan rumah tangga yang terdaftar di Bursa Efek Indonesia. Tujuan penelitiannya (1) menganalisis pengaruh profitabilitas terhadap struktur modal,(2) menganalisis pengaruh struktur aktiva terhadap struktur modal,(3) menganalisis pengaruh risiko bisnis terhadap struktur modal,(4) membandingkan hasil analisis keseluruhan baik dengan veriabel kontrol maupun tanpa variabel kontrol ukuran perusahaan.

\section{KAJIAN PUSTAKA}

\section{Pecking Order Theory}

Model lain dari struktur modal dikemukakan oleh Myers dan Maljuf dalam Pecking Order Theory (POT) pada tahun 1984. Secara ringkas, POT menyatakan bahwa keputusan pendanaan perusahaan memiilki suatu hierarki. Perusahaan akan lebih cenderung untuk menggunakan sumber pendanaan internal yaitu dari laba ditahan dan depresiasi terlebih dahulu, daripada dana eksternal dalam aktivitas pendanaan. Hanya jika perusahaan tidak memiliki dana internal yang memadai, maka dana eksternal akan dipilih sebagai alternatifnya. Jika dana eksternal dibutuhkan maka perusahaan akan lebih cenderung untuk menggunakan hutang daripada ekuitas (Joni \& Lina, 2010) Dalam teori POT terdapat beberapa asumsi yang digunakan; 1) perusahaan haan cenderung memilih pendanaan internal terlebih dahulu (laba ditahan dan depresiasi) sehingga pendanaan eksternal (hutang dan saham) alternatif terakhir, 2) Jika perusahaan menggunakan dana eksternal maka pemilihan dilakukan berjenjang mulai dari yang paling aman sampai yang paling berisiko. Seperti mulai dari sekuritas hutang, obligasi konversi, saham preferen dan yang terakhir dari saham biasa, 3) Kebijakan dividen yang ketat dimana pihak manajemen akan menetapkan jumlah pembayaran dividen dan target dividend payout ratio (DPR) yang konstan dan dalam periode tertentu jumlah pembayaran dividen tidak akan berubah baik perusahaan tersebut untung maupun rugi, dan 4) Dalam mengantisipasi kekurangan atau kelebihan dari persediaan arus kas dengan adanya kebi- jakan dividen dan fluktuasi dari tingkat keuntungan dan kesempatan investasi maka jika kurang pertama kali perusahaan akan mengambil dari portofolio investasi lancar yang tersedia.

Trade Off Theory 
Menurut (Sudana, 2002,153) keputusan perusahaan dalam meggunakan hutang didasarkan atas keseimbangan dalam penghematan pajak dan biaya kesulitan dalam keuangan.Trade-off theory menyatakan bahwa perusahaan menukarkan manfaat pajak dari keuntungan pendanaan melalui hutang dengan tingkat suku bunga dan biaya kebangkrutan yang lebih tinggi (Brigham \& Huuston, 2006,36). Trade-off theory, menyatakan bahwa tingkat hutang yang optimal tercapai ketika penghematan pajak mencapai jumlah yang maksimal terhadap biaya kesulitan keuangan, artinya terjadi keseimbangan antara manfaat dan pengorbanan yang timbul akibat penggunaan hutang.

\section{Signaling Theory}

Teori signal menurut (Brigham \& Huuston, 2006,40).adalah suatu tindakan yang diambil manajemen perusahaan yang memberi petunjuk kepada para investor tentang bagaimana manajemen memandang prospek perusahaan. Informasi perusahaan yang dipublikasikan akan memberi signal bagi investor dalam pengambilan keputusan dalam berinvestasi. Berdasarkan signaling theory perusahaan yang mampu menghasilkan laba akan cenderung meningkatkan jumlah utangnya, karena dengan tambahan pembayaran bunga akan diimbangi dengan laba sebelum pajak (Sudana, 2002).

\section{Profitabilitas}

Profit merupakan salah satu indikator keberhasilan perusahaan dalam menjalankan bisnisnya. Profitabilitas adalah kemampuan perusahaan untuk memeperoleh laba dari kegiatan bisnis yang dilakukannya. Profitabilitas mencakup seluruh pendapatan dan biaya yang dikeluarkan oleh perusahaan sebagai penggunaan aset dan pasiva dalam suatu periode tertentu. Sementara itu profitabilitas menurut (Harahap, 2007) adalah yang menggambarkan kemampuan perusahaan mendapatkan laba melalui semua kemampuan, dana sumber yang ada seperti kegiatan penjualan, kas, modal, jumlah karyawan, jumlah cabang, dan sebagainya. Menurut (Hery, 2016) rasio ini dapat dibedakan menjadi dua jenis, yaitu Rasio Tingkat Pengembalian atas Investasi dan Rasio Kinerja Operasi. Rasio Tingkat Pengembalian Investasi adalah rasio yang digunakan untuk menilai kompensasi finansial atas penggunaan aset atau ekuitas terhadap laba bersih. Rasio ini terdiri dari ;(a) hasil pengembalian atas aset (Return on Asset), merupakan rasio yang menunjukkan hasil atas penggunaan aset perusahaan dalam menciptakan laba bersih,(b) hasil pengembalian atas Ekuitas (Return on Equity), merupakan rasio yang menunjukkan hasil atas penggunaan ekuitas perusahaan dalam menciptakan laba bersih. Rasio Kinerja Operasi adalah rasio yang digunakan untuk mengevaluasi margin laba dari aktivitas operasi (Penjualan). Rasio ini terdiri atas;Marjin Laba Kotor (Gross Profit Margin), merupakan rasio yang digunakan untuk mengukur besarnya presentase laba kotor atas penjualan bersih; Marjin Laba Operasional (Operating Profit Margin), merupakan rasio yang digunakan untuk mengukur besarnya persentase laba operasional atas penjualan bersih;Marjin Laba bersih (Net Profit Margin), merupakan rasio yang digunakan untuk mengukur besarnya presentase laba bersih atas penjualan bersih.

\section{Risiko Bisnis}

Risiko bisnis merupakan risiko aset perusahaan jika perusahaan tidak menggunakan hutang. Risiko bisnis berkaitan dengan ketidakpastian pendapatan karena terdapatnya variabilitas dalam penjualan produk, pelanggan, dan bagaimana produk dihasilkan perusahaan. Intinya pembiayaan dengan utang umumnya akan meningkatkan tingkat pengembalian yang diharapkan untuk suatu investasi, tetapi utang juga meningkatkan tingkat risiko investasi bagi pemilik perusahaan, yaitu para pemegang saham biasa. Meningkatnya utang dapat diartikan bahwa operasi perusahaan dilakukan dengan menggunakan utang atau sumber dana eksternal. Apabila hal tersebut terjadi secara terus menerus maka dapat meningkatkan risiko kemungkinan perusahaan mengalami kebangkrutan. Risiko dalam hal ini adalah risiko bisnis (Business Risk) sebagai faktor penentu kebijakan struktur modal perusahaan, menggunakan standar deviasi dari laba sebelum bunga dan pajak (EBIT) dibanding dengan total aset (Yuliana Ria Savitri \& Vivi Lestari, 2015) (Tansyawati \& Asyik, 2015). Risiko bukanlah suatu rasio, sehingga satuan ukurannya bukanlah persen, merupakan perbandingan antara standar deviasi dari laba operasi dengan total asset (Astakoni \& Utami, 2019)

\section{Struktur Aktiva}

Aset/aktiva adalah segala sumber daya dan harta yang dimiliki perusahaan untuk digunakan dalam operasinya. Suatu perusahaan pada umumnya memiliki dua jenis aset yaitu aset lancar dan aset tetap. Kedua unsur aset ini akan membentuk struktur aset. Sedangkan menurut Syamsudin, 
(2004,56) struktur aktiva adalah penentuan berapa besar alokasi dana untuk masing-masing komponen aktiva, baik dalam aktiva lancar maupun dalam aktiva tetap. Struktur aset menggambarkan sebagian jumlah aset yang dapat dijadikan jaminan (collateral value of assets). Kebanyakan perusahaan industri yang sebagian besar modalnya tertanam dalam aset tetap akan mengutamakan pemenuhan modalnya dari modal yang permanen yaitu modal sendiri, sedangkan hutang bersifat sebagai pelengkap (Brigham, E F, dan Houston, 2010, 124). Struktur aset ini menggambarkan alokasi untuk masing-masing komponen aset, baik aset lancar maupun aset tetap menurut Syamsudin, $(2004,55))$. Lebih jauh dijelaskan struktur aset adalah perbandingan total aset tetap dengan total asset (Astakoni \& Utami, 2019). Struktur aktiva menurut Brigham, E F, dan Houston, $(2010,129)$ struktur aktiva adalah perimbangan atau perbandingan antara aktiva tetap dan total aktiva.

\section{Ukuran Perusahaan}

Seftianne, (2011), menyatakan bahwa penentuan besar kecilnya ukuran perusahaan dapat ditentukan berdasarkan total penjualan, total aktiva, rata-rata tingkat penjualan dan rata-rata total aktiva. Ukuran perusahaan (firm size) digunakan sebagai variabel kontrol untuk menghindari bias pengaruh variabel independen terhadap variabel dependen (Silaban \& Pengestuti, 2017). Dalam beberapa literatur (Harsono, 2002) variabel kontrol sering juga disebut covariate.Variabel kontrol adalah variabel bebas (prediktor) yang efeknya terhadap variabel kriteria dikontrolkan oleh peneliti dengan cara menjadikan pengaruhnya netral. Arti netral di sini adalah sebelum variabel-variabel prediktor utama dimasukkan dalam analisis, variabel kontrol harus diuji dahulu pengaruhnya, sehingga ketika variabel prediktor utama dimasukkan dalam pengujian, peneliti dapat mengetahui perubahan tingkat pengaruhnya terhadap variabel kriteria. Perusahaan besar merupakan emiten yang banyak disoroti, sehinggakebijakan pendanaannya sangat perlu dilakukan secara hati hati. Untuk itu ukuran perusahaan (firm size) dalam penelitan ini dijadikan variabel kontrol untuk mengetahui apakah variabel firm size ini perlu dinetralisir,dikeluarkan, atau dipertahankan tetap (Widianingsih, 2018). Atinc, Simmering, \& Kroll, (2012) menyatakan bahwa variabel kontrol dapat memainkan diri sebagai variabel pengganggu, moderator dan variabel penekan.

\section{Pengaruh Profitabilitas terhadap Struktur Modal}

Teori Pecking-Order (POT) menjelaskan perusahaan dengan profitabilitas yang lebih besar memiliki ratio hutang yang lebih kecil (Alipour, Mohammadi, \& Derakhshan, 2015). Faktanya perusahaan dengan profitabilitas yang lebih tinggi tidak membutuhkan pendanaan eksternal dan sering kali menggunakan pendanaan internal. Oleh karena itu perusahaan memiliki lebih sedikit hutang dalam struktur modalnya. Hal ini menunjukkan bahwa perusahaan yang sangat menguntungkan akan cenderung membiayai investasi dengan laba ditahan dibandingkan dengan hutang. Tingkat keuntungan yang tinggi memungkinkan untuk mendapatkan sebagian besar pendanaan dari laba ditahan (Handayani \& Darma, 2018). Berdasarkan paparan ini dapat dikatakan, semakin tinggi profitabilitas, maka semakin kecil proporsi utang di dalam struktur modal perusahaan. Konsep ini sejalan dengan temuan Wardita \& Astakoni, (2018), Thippayana, (2014),Utami, (2019), Kaliman \& Wibowo, (2017), Handayani \& Darma, (2018), Joni \& Lina, (2010), Rahma, Muslim, \& Nalurita, (2019), Çitak \& Ersoy, (2012) yang mendapatkan profitabilitas berpengaruh signifikan negative terhadap struktur modal.Berdasarkan konsep dan hasil riset sebelumnya dapat diusulkan hipotesis sebagai berikut; $(\mathrm{Hl})$ profitabilitas berpengaruh signifikan negatif terhadap struktur modal.

\section{Pengaruh Risiko Bisnis terhadap Struktur Modal}

Brigham \& Huuston, $(2006,204)$ menyatakan bahwa risiko bisnis adalah ketidakpastian dalam proyeksi perusahaan atas tingkat pengembalian (laba) atau ekuitasnya di masa mendatang. Risiko bisnis dapat berubah dari waktu ke waktu. Risiko bisnis berhubungan dengan jenis usaha yang dipilih dari kondisi ekonomi yang dihadapi. Perusahaan dengan risiko bisnis yang tinggi seharusnya menggunakan utang yang lebih sedikit untuk menghindari risiko kebangkrutan (Brigham \& Huuston, $(2006,209)$.Hal tersebut sejalan dengan penelitian yang dilakukan oleh Kaliman \& Wibowo, (2017),Utami, (2019) menunjukkan bahwa risiko bisnis berpengaruh negatif dan signifikan terhadap struktur modal perusahaan, Berdasarkan konsep dan kajian empiris sebelumnya maka diusulkan hipotesis sebagai berikut $\mathrm{H}_{2}$ : Risiko Bisnis bepenganuh signifikan negatif terhadap struktur modal 


\begin{abstract}
Pengaruh Struktur Aktiva terhadap Struktur Modal
Menurut Riyanto, $(2008,204)$ struktur aktiva mencerminkan dua komponen aktiva secara garis besar dalam komposisinya, yaitu aktiva lancar dan aktiva tetap. Struktur Aktiva adalah faktor yang mempengaruhi pembuatan keputusan struktur modal. Semakin besar struktur aktiva maka semakin besar penggunaan hutang pada struktur modalnya. Hal ini menunjukkan bahwa semakin banyak jumlah aktiva tetap yang bisa digunakan sebagai jaminan hutang oleh perusahaan. Sedangkan, makin kecil struktur aktiva yang dimiliki oleh suatu perusahaan, maka semakin kecil pula kemampuan perusahaan tersebut agar dapat menjamin hutang jangka panjang (Alipour et al., 2015) Pendapat ini didukung oleh penelitian yang dilakukan oleh (Jalil, 2018) menunjukkan bahwa struktur aktiva dapat dianggap sebagai variabel penjelas dari struktur modal pada sektor makanan dan minuman yang terdaftar di bursa efek Indonesia, Juga yang didapat (Mas'ud, 2008), (Joni \& Lina, 2010), menemukan struktur aktiva berpengaruh positif terhadap struktur modal, maka hipotesis yang diusulkan adalah: $\mathrm{H}_{3}$ : Struktur Aktiva pengaruh signifikan positif terhadap struktur modal.
\end{abstract}

\title{
Pengaruh Ukuran Perusahaan terhadap Struktur Modal
}

Ukuran perusahaan (Firm Size) merupakan salah satu faktor yang dipertimbangkan perusahaan dalam menentukan berapa besar kebijakan keputusan pendanaan (struktur modal) dalam memenuhi ukuran atau besarnya asset perusahaan (Astakoni \& Utami, 2019). Ukuran Perusahaan menurut Riyanto $(2008,207)$ menggambarkan besar kecilnya suatu perusahaan yang ditunjukkan dari total aktiva, jumlah penjualan, rata-rata penjualan dan rata-rata total aktiva. Total aset dijadikan sebagai indikator ukuran perusahaan karena sifatnya jangka panjang dibandingkan dengan penjualan (Astakoni \& Mariani, 2018). Jika perusahaan semakin besar maka semakin besar pula dana yang akan dikeluarkan, baik itu dari kebijakan hutang atau modal sendiri (equity) dalam mempertahankan atau mengembangkan perusahaan. Namun begitu argumen yang bisa dikemukakan disini adalah large firm akan memiliki free cash flow yang tinggi, sehingga bila memerlukan tambahan dana untuk membiayai investasi baru, maka perusahaan tersebut akan menggunakan sumber pendanaan yang murah yaitu sumber pendanaan dari dalam yang berupa retained earning. Seandainya sumber pendanaan dari dalam perusahaan, tidak mencukupi, perusahaan akan beralih pada sumber pendanaan dari luar yang berasal dari hutang daripada penerbitan saham baru.).Penelitian yang dilakukan Carlson \& Wu, (2012), Atinc et al., (2012), Rahma et al., (2019) menyatakan bahwa semakin besar ukuran perusahaan, semakin kecil jumlah proporsi hutang yang digunakan. Berdasarkan paparan diatas maka hipotesis keempat (H4) : Ukuran perusahaan (Firm Size) berpengaruh signifikan negatif terhadap struktur modal.

\section{METODE}

\section{Jenis Dan Pendekatan Penelitian}

Berdasarkan pada jenis penjelasan ilmu yang akan dihasilkan maka penelitian dapat dibedakan menjadi penelitian kausalitas dan penelitian non-kausalitas (komparatif) (Ferdinand, 2011,7). Dalam penelitian kausalitas (cause-effect) pada studi kali ini diarahkan untuk menggambarkan dan menjelaskan kedudukan variabel yang diteliti serta hubungan antara satu variabel dengan variable yang lain.

Menurut Sugiyono, $(2021,8)$ pendekatan atau filosofi yang bisa digunakan dalam penelitian bisa mengambil tiga model yaitu pendekatan kuantitatif, pendekatan kualitatif dan pendekatan kombinasi atau campuran (Mix Method Research,MMR). Pendekatan kuantitatif merupakan model penelitian berdasarkan paradigma positivisme/rasionalisme yang dipilih dalam penelitian ini. Oleh karena itu berarti studi ini berdasarkan populasi yang jelas dan dengan sampel tertentu, pengumpulan data menggunakan instrument penelitian dan analisis yang digunakan menggunakan pendekatan statistik (kuantitatif) serta dengan tujuan untuk menguji hipotesis yang telah dirumuskan.

\section{Populasi dan Sampel}

Populasi adalah keseluruhan obyek yang diteliti dan terdiri atas sejumlah individu baik yang sifatnya terbatas maupun tidak terbatas (Sumarni \& Wahyuni, 2005,69). Ferdinand, $(2011,215$ ) menyatakan populasi adalah gabungan dari seluruh elemen yang berbentuk peristiwa, orang, hal atau orang yang memiliki karakteristik yang serupa sehingga menjadi pusat perhatian dari peneliti. 
Populasi dalam penelitian ini adalah seluruh perusahaan manufaktur sektor kosmetik dan barang keperluan rumah tangga yang terdaftar di Bursa Efek Indonesia periode 2016-2020 sebanyak tujuh perusahaan. Sampel dalam penelitian ini, diambil sesuai dengan kriteria yang telah ditetapkan. Berdasarkan ketentuan yang telah ditetapkan terpilih sampel sejumlah lima perusahaan seperti pada tabel 1 berikut ini:

Tabel 1

Sampel Penelitian

\begin{tabular}{ccc}
\hline No & Kode Saham & Nama Perusahaan \\
\hline 1 & ADES & Akasha Wira Internasional Tbk \\
2 & MBTO & Martina Berto Tbk \\
3 & TCID & Mandom Indonesia Tbk \\
4 & MRAT & Mustika Ratu Tbk \\
5 & UNVR & Unilever Indonesia Tbk \\
\hline
\end{tabular}

Sumber dan Jenis Data

Data yang dibutuhkan dalam penelitian dapat berasal dari sumber primer dan atau dari sumbersumber sekunder (Ferdinand, 2011,29). Data dari sumber primer yang sering disebut data primer merupakan data yang diperoleh oleh peneliti secara langsung dari sumbernya.Sedangkan data sekunder adalah data yang diperoleh peneliti secara tidak langsung dari sumbernya melainkan telah dikumpulkan oleh pihak lain (Dachlan, 2014,19). Dalam penelitian ini sumber datanya didapat dari situs perusahaan masing-masing dalam bentuk laporan neraca dan laporan laba/rugi periode 20162020.Jenis data menurut sifatnya dapat dikelompokkan menjadi dua yaitu data kualitatif dan data kuantitatif (Supranto, 2008,8) Data kualitatif adalah data yang tidak berbentuk angka (non-numeric), dalam penelitian ini seperti sejarah masing-masing perusahaan sampel, struktur organisasi dan penjelasannya serta data jenis barang/produk maupun daerah pasar perusahaan. Data kuantitatif adalah data yang dinyatakan dalam bentuk angka (numeric). Dalam penelitian ini dapat dalam bentuk angka-angka yang tertuang dalam pos - pos yang terdapat pada laporan Neraca dan laporan Laba/ Rugi Selain jenis data diatas maka data dapat pula dikelompokkan menurut dimensi waktu menjadi tiga (Kuncoro, 2001,24; Ghozali \& Ratmono, 2014,195) yaitu data runtut waktu (times series data), data silang tempat (cross section data) dan data gabungan runtut waktu dan silang tempat yang sering disebut dengan data panel (pooling data).

\section{Definisi Operasional dan Pengukuran Variabel}

Variabel penelitian merupakan segala sesuatu yang dapat diberi bermacam-macam nilai (Indriantoro \& Supomo, 2009,61). Lebih jauh dijelaskan bahwa tipe variable dapat diklasifikasikan berdasarkan fungsi variable dalam hubungan antar variable yaitu variable independen (independent variable), variable dependen (dependent variable), variable moderating (moderating variable) dan variable intervening (intervening variable) dan variabel kontrol (Carlson \& Wu, 2012), (Atinc et al., 2012). Dalam penelitian ini melibatkan 3 jenis variabel yaitu variabel dependen dan variabel independen serta variabel kontrol.

Variabel Dependen (Y), merupakan variabel yang dipengaruhi atau menjadi akibat karena adanya variabel independen. Dalam penelitian ini yang menjadi variabel dependen (terikat) adalah struktur modal (Y),Variabel Independen (X), dalam penelitian ini adalah profitabilitas (X1), risiko bisnis (X2), struktur aktiva (X3). Variabel Kontrol,Variabel kontrol (controling variable) merupakan variabel bebas (independent variable) yang dimasukkan dalam model yang bisa berfungsi sebagai pengganggu, moderator dan variabel penekan.(Carlson \& Wu, 2012),(Atinc et al., 2012). Dalam studi ini yang dimasukkan sebagai variabel kontrol adalah ukuran perusahaan (K). Untuk lebih jelasnya definisi dan pengukuran masing-masing variabel penelitian yang diangkat dalam studi ini, akan disajikan lewat tabel 2 berikut: 
Wacana Ekonomi (Jurnal Ekonomi Bisnis dan Akuntansi), 20 (2) 2021, 151

Ukuran Perusahan Sebagai Variabel Kontrol Dalam Determinan Struktur Modal Manufaktur

Tabel 2

\begin{tabular}{|c|c|c|c|}
\hline Variabel & Definisi Operasional & $\begin{array}{c}\text { Pengukuran variable dan } \\
\text { sumber acuan }\end{array}$ & Skala \\
\hline $\begin{array}{c}\text { Variabel dependen } \\
\text { (Y): } \\
\text { Struktur Modal }\end{array}$ & $\begin{array}{l}\text { Struktur modal merupakan } \\
\text { kombinasi sumber pendanaan } \\
\text { internal dan eksternal yang } \\
\text { digunakan perusahaan untuk } \\
\text { membiayai kebutuhan } \\
\text { operasinya }\end{array}$ & $\begin{array}{l}\text { DAR yaitu Total Asset to } \\
\text { Total Debt } \\
\text { (Mahardika, Khafid, \& } \\
\text { Agustina, 2014) } \\
\text { (Hartoyo, Khafid, \& } \\
\text { Agustina, 2014), (Astakoni } \\
\text { \& Nursiani, 2020) }\end{array}$ & Ratio \\
\hline \multicolumn{4}{|l|}{$\begin{array}{c}\text { Variabel } \\
\text { independen: }\end{array}$} \\
\hline Profitabilitas $\left(\mathrm{X}_{1}\right)$ : & $\begin{array}{c}\text { Profitabilitas merupakan } \\
\text { kemampuan perusahaan untuk } \\
\text { menghasilkan laba atas asset } \\
\text { yang dimiliki }\end{array}$ & $\begin{array}{l}\text { ROA,Operating Profit to } \\
\text { Total Asset (Alipour, } \\
\text { Mohammadi , \& } \\
\text { Derakhshan, 2015), } \\
\text { (Karina, 2015) }\end{array}$ & Ratio \\
\hline Risiko Bisnis $\left(\mathrm{X}_{2}\right)$ & $\begin{array}{l}\text { Risiko bisnis suatu kondisi } \\
\text { yang terjadi karena suatu } \\
\text { perusahaan sedang mengalami } \\
\text { kesulitan keuangan }\end{array}$ & $\begin{array}{c}\text { Standard Deviasi dari } \\
\text { (laba operasi) dibagi total } \\
\text { asset } \\
\text { (Yuliana Ria Savitri \& } \\
\text { Vivi Lestari, 2015) } \\
\text { (Tansyawati \& Asyik, } \\
\text { 2015) }\end{array}$ & Ratio \\
\hline $\begin{array}{l}\text { Struktur Aktiva } \\
\left(\mathrm{X}_{3}\right)\end{array}$ & $\begin{array}{c}\text { Struktur aktiva merupakan } \\
\text { proporsi aktiva tetap dari } \\
\text { seluruh aktiva perusahaan. }\end{array}$ & $\begin{array}{l}\text { Aset Tetap dibagi Total } \\
\text { asset } \\
\text { (Astakoni \& Utami, 2019) }\end{array}$ & Ratio \\
\hline $\begin{array}{l}\text { Variabel Kontrol : } \\
\text { Ukuran perusahaan } \\
(\mathrm{K})\end{array}$ & $\begin{array}{l}\text { Ukuran Perusahaan adalah } \\
\text { jumlah aset yang dimiliki oleh } \\
\text { suatu perusahaan. }\end{array}$ & $\begin{array}{c}\text { Ln Total aset (Astakoni \& } \\
\text { Wardita, 2020) }\end{array}$ & Ratio \\
\hline
\end{tabular}

\section{Metode Pengumpulan Data}

Metode pengumpulan data penelitian ini dilakukan melalui metode dokumentasi. Metode ini digunakan karena sesuai dengan permasalahan dan tujuan penelitian yang diangkat. Memahami dan menelaah laporan keuangan baik neraca dan laba rugi, menganalisis laporan keuangan perusahaan melalui dokumentasi yang diperoleh dari situs masing- masing yang menjadi objek penelitian.

\section{Teknik Analisis Data}

Teknik analisis data dalam penelitian ini menggunakan pendekatan statistik. Pendekatan statistik dapat dibedakan menjadi statistik deskriptif dan statistik inferensial (Rimbawan, 2013,1). Analisis statistik deskriptif, merupakan metode yang digunakan untuk mengumpulkan, mengolah, menyajikan dan menganalisis data kuantitatif secara deskriptif. Dalam penelitian ini analisis deskriptif digunakan untuk menggambarkan nilai maksimal, minimal, rata-rata dari masing-masing variable penelitian.Analisis statistik inferensial, suatu metode yang berkaitan dengan cara-cara menarik simpulan tentang karakteristik populasi yang didasarkan pada data yang diambil berdasarkan sampel. Analisis statistik inferensial dalam penelitian ini pengolahannya menggunakan bantuan pengolah data Eviews Versi 12, mengingat data yang dianalisis berbentuk data panel. Adapun tahapan atau langkah-langkahnya adalah dengan melakukan analisis kuantitatif sebagai berikut (Bawono \& Shina, 2018,135); Estimasi model regresi data panel, Pemilihan model regresi data panel. Uji asumsi klasik, Uji Hipotesis dan uji kelayakan model.

\section{HASIL DAN PEMBAHASAN}

\section{Hasil Penelitian}

Analisis Statistik Deskriptif 
Gambaran suatu data bisa diamati dari statistik deskriptif melalui nilai rata-rata (mean),median, standar deviasi, maksimum dan minimum dari masing- masing variabel. Untuk memperoleh gambaran dan penjelasan mengenai deskripsi masing-masing variabel penelitian dapat dilihat pada tabel 3

Tabel 3

Statistik Deskriptif Variabel Penelitian

\begin{tabular}{cccccc}
\hline & Y & X1 & X2 & X3 & K \\
\hline Mean & 41.78457 & 1.964312 & 4.296960 & 40.43816 & 25.40456 \\
Median & 38.83160 & 1.482800 & 4.354400 & 43.13270 & 27.28850 \\
Maximum & 75.95590 & 16.89240 & 13.56280 & 100.0000 & 30.65880 \\
Minimum & 18.39470 & -21.19670 & 0.000100 & 0.000100 & 13.55090 \\
Std. Dev. & 19.11761 & 8.854122 & 4.096164 & 28.57311 & 6.134024 \\
Observations & 25 & 25 & 25 & 25 & 25 \\
\hline
\end{tabular}

Berdasarkan dari hasil analisis statistik deskriptif variabel penelitian pada tabel 3 maka variabel struktur modal (Y) memiliki nilai minimum sebesar 18,39470\%, nilai maksimum sebesar $75,95590 \%$, nilai rata-rata (mean) sebesar $41,78457 \%$, median sebesar $38,83160 \%$ dan standar deviasi sebesar 19,11761\% Untuk variabel profitabilitas (X1) memiliki nilai minimum sebesar $21,19670 \%$, nilai maksimum sebesar $16,89240 \%$, nilai rata-rata (mean) sebesar $1,964312 \%$, median sebesar 1,48280\% dan standar deviasi 8,854122\%,. Untuk variabel risiko bisnis (X2) memiliki nilai minimum sebesar $0,000100 \%$, nilai maksimum sebesar $13,56280 \%$, nilai rata-rata (mean) sebesar 4,296960\%, median sebesar 4,354400\% dengan standar deviasi sebesar 4,096164\%. Untuk variabel Struktur aktiva (X3) memiliki nilai minimum sebesar $0,000100 \%$, nilai maksimum sebesar $100,0000 \%$, nilai rata-rata (mean) sebesar $40,43816 \%$, median sebesar $43,13270 \%$ dengan standar deviasi sebesar 28,57311\%. Untuk variabel Ukuran perusahaan $(\mathrm{K})$ memiliki nilai minimum sebanyak sebesar 13,55090, nilai maksimum sebesar 30,65880, nilai rata-rata (mean) sebesar 25,40456, median sebesar 27,28850dengan standar deviasi sebesar 6,134024.

\section{Analisis Statistik Inferensial}

Estimasi regresi data panel melalui bantuan pengolah data program Eviews dapat dilakukan melalui tiga cara yaitu Common effect model (CEM), Fixed effect model (FEM) dan Random effect model (REM).Hasil estimasi melalui tiga pendekatan diatas akan dipilih yang paling tepat sesuai ketentuan yang ada. Berdasarkan Uji Chow model yang terpilih adalah Fixed Effect Model, sehingga dilanjutkan dengan melakukan Uji Housman. Melalui Uji Housmen dimana hasilnya diputuskan model terbaik dengan data yang ada adalah Fixed Effect Model (FEM)

Tabel 4

Persamaan Regresi Melalui FEM dengan Variabel Kontrol

\begin{tabular}{|c|c|c|c|c|}
\hline Variable & Coefficient & Std. Error & t-Statistic & Prob. \\
\hline $\mathrm{C}$ & 22.41198 & 704.1841 & 0.031827 & 0.9750 \\
\hline $\mathrm{X} 1$ & -0.372447 & 0.254616 & -1.462779 & 0.1629 \\
\hline $\mathrm{X} 2$ & 4.412901 & 2.986196 & 1.477767 & 0.1589 \\
\hline $\mathrm{X} 3$ & 0.138505 & 0.070933 & 1.952613 & 0.0486 \\
\hline $\mathrm{K}$ & -0.175511 & 27.31777 & -0.006425 & 0.9950 \\
\hline \multicolumn{5}{|c|}{ Effects Specification } \\
\hline \multicolumn{5}{|c|}{ Cross-section fixed (dummy variables) } \\
\hline Root MSE & 4.759204 & \multicolumn{2}{|l|}{ R-squared } & 0.935445 \\
\hline Mean dependent var & 41.78457 & \multicolumn{2}{|c|}{ Adjusted R-squared } & 0.903167 \\
\hline S.D. dependent var & 19.11761 & \multicolumn{2}{|c|}{ S.E. of regression } & 5.949006 \\
\hline Akaike info criterion & 6.678038 & \multicolumn{2}{|c|}{ Sum squared resid } & 566.2507 \\
\hline Schwarz criterion & 7.116833 & \multicolumn{2}{|c|}{ Log likelihood } & -74.47548 \\
\hline Hannan-Quinn criter. & 6.799741 & \multicolumn{2}{|l|}{ F-statistic } & 28.98129 \\
\hline Durbin-Watson stat & 2.131904 & \multicolumn{2}{|c|}{ Prob(F-statistic) } & 0.000000 \\
\hline
\end{tabular}


Wacana Ekonomi (Jurnal Ekonomi Bisnis dan Akuntansi), 20 (2) 2021, 153

Ukuran Perusahan Sebagai Variabel Kontrol Dalam Determinan Struktur Modal Manufaktur

Tabel 5

Persamaan Regresi Melalui FEM tanpa Variabel Kontrol

\begin{tabular}{|c|c|c|c|c|}
\hline Variable & Coefficient & Std. Error & t-Statistic & Prob. \\
\hline $\mathrm{C}$ & 17.88802 & 7.432984 & 2.406573 & 0.0278 \\
\hline $\mathrm{X} 1$ & -0.372625 & 0.245548 & -1.517524 & 0.1475 \\
\hline $\mathrm{X} 2$ & 4.429632 & 1.418017 & 3.123822 & 0.0062 \\
\hline $\mathrm{X} 3$ & 0.138348 & 0.064601 & 2.141596 & 0.0470 \\
\hline \multicolumn{5}{|c|}{ Effects Specification } \\
\hline \multicolumn{5}{|c|}{ Cross-section fixed (dummy variables) } \\
\hline Root MSE & 4.759211 & R-squared & & 0.935445 \\
\hline Mean dependent var & 41.78457 & Adjusted R-squared & & 0.908863 \\
\hline S.D. dependent var & 19.11761 & S.E. of regression & & 5.771391 \\
\hline Akaike info criterion & 6.598041 & Sum squared resid & & 566.2521 \\
\hline Schwarz criterion & 6.988081 & Log likelihood & & -74.47551 \\
\hline Hannan-Quinn criter. & 6.706221 & F-statistic & & 35.19147 \\
\hline Durbin-Watson stat & 2.130229 & Prob(F-statistic) & & 0.000000 \\
\hline
\end{tabular}

\section{Uji asumsi klasik}

Uji asumsi klasik meliputi 4 uji yaitu uji normalitas residual, uji multikolinieritas, uji autokorelasi dan uji heteroskedastisitas

Uji normalitas residual

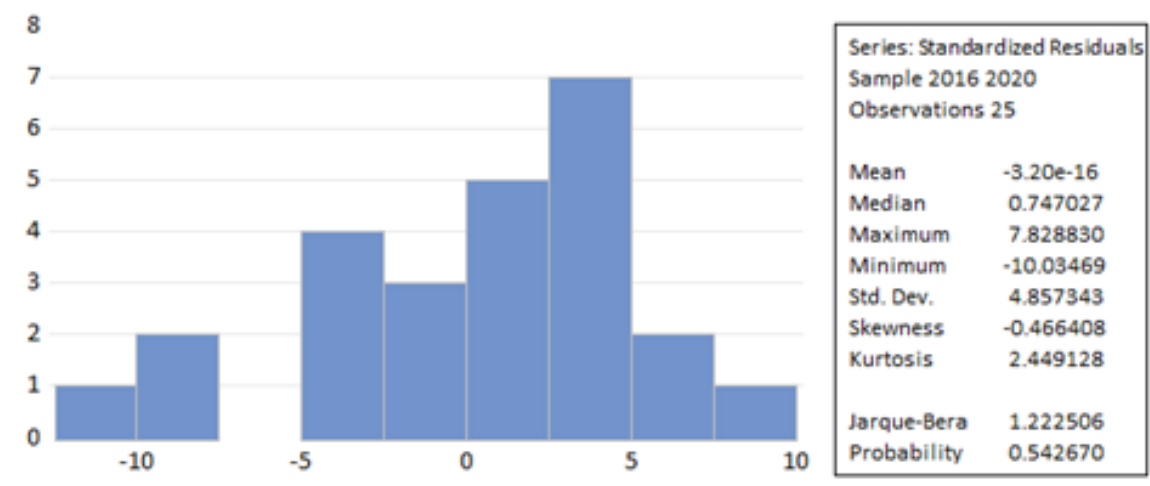

Gambar 1

Hasil uji Normalitas residual

Sesuai gambar 1 dapat dijelaskan distribusi dari residual /sisaan mengikuti distribusi normal atau tidak. Hasil yang didapat dimana nilai probabilitasnya sebesar $0,542670(>0,05)$ maka residual berdistribusi normal

Uji Multikolinearitas

Tabel 6

Hasil uji multikolinieritas

\begin{tabular}{ccccc}
\hline & $\mathrm{X} 1$ & $\mathrm{X} 2$ & $\mathrm{X} 3$ & $\mathrm{~K}$ \\
\hline $\mathrm{X} 1$ & 1.000000 & -0.380539 & 0.081236 & -0.540296 \\
$\mathrm{X} 2$ & -0.380539 & 1.000000 & 0.274245 & -0.103302 \\
$\mathrm{X} 3$ & 0.081236 & 0.274245 & 1.000000 & -0.413371 \\
$\mathrm{~K}$ & -0.540296 & -0.103302 & -0.413371 & 1.000000 \\
\hline
\end{tabular}

Uji multikolinearitas dalam studi ini menggunakan pendekatan matriks korelasi. Sesuai tabel 6 tidak ditemukan korelasi antar variabel independen yang lebih besar dari 0,90 ( $\mathrm{r}<-, 90)$, itu berarti tidak ada gejala multikolinearitas dari data yang ada. 
Uji Autokorelasi

Uji autokorelasi bertujuan untuk menguji apakah dalam suatu model regresi linier ditemukan adanya korelasi antar kesalahan pengganggu (residual) pada periode ke-t dengan periode ke t-1 (sebelumnya). Sesuai tabel 7 dikaitkan dengan ketentuan yang ada dimana hasil Prob. Chi-Square sebesar 0,0532 ( $>0$,05) maka berarti model regresi yang didapat tidak mengandung gejala autokorelasi.

\section{Tabel 7}

Hasil uji autokorelasi

Breusch-Godfrey Serial Correlation LM Test:

Null hypothesis: No serial correlation at up to 2 lags

\begin{tabular}{llll}
\hline \hline F-statistic & 7.657721 & Prob. F(2,18) & 0.0039 \\
Obs*R-squared & 11.49275 & Prob. Chi-Square(2) & 0.0532 \\
\hline \hline
\end{tabular}

Uji Heteroskesdastisitas

Tabel 8 Hasil uji heteroskesdastisitas

Heteroskedasticity Test: White

Null hypothesis: Homoskedasticity

\begin{tabular}{llll}
\hline \hline F-statistic & 5.854754 & Prob. F(14,10) & 0.0040 \\
Obs*R-squared & 22.28162 & Prob. Chi-Square(14) & 0.0730 \\
Scaled explained SS & 8.899747 & Prob. Chi-Square(14) & 0.8374 \\
\hline \hline
\end{tabular}

Uji heteroskesdastisitas bertujuan untuk menguji apakah suatu residual hamogen atau heterogen. Dalam studi ini dilakukan melalui uji White. Sesuai dengan tampilan tabel 8 nilai Prob. Chi-Square sebesar 0,7030 (>0,05) maka data yang dianalisis tidak ada masalah heteroskesdastisitas.

Uji Model (Uji Determinasi dan Uji F statistik)

Uji model dalam studi ini dilihat dari koefisien determinasi dan uji F statistik. Uji koefisien determinansi digunakan untuk mengukur seberapa besar variabel bebas dapat menjelaskan variabel terikat.

Tabel 9

Hasil Uji Determinasi dan Uji F Statistik

\begin{tabular}{lllr}
\hline \hline Root MSE & 4.759204 & R-squared & 0.935445 \\
Mean dependent var & 41.78457 & Adjusted R-squared & 0.903167 \\
S.D. dependent var & 19.11761 & S.E. of regression & 5.949006 \\
Akaike info criterion & 6.678038 & Sum squared resid & 566.2507 \\
Schwarz criterion & 7.116833 & Log likelihood & -74.47548 \\
Hannan-Quinn criter. & 6.799741 & F-statistic & 28.98129 \\
Durbin-Watson stat & 2.131904 & Prob(F-statistic) & 0.000000 \\
\hline \hline
\end{tabular}

Pada tabel 9 dapat dilihat nilai adjusted R_squared sebesar 0,903167 atau 90,32\% yang berarti bahwa variabel struktur modal dapat dijelaskan oleh variabel profitabilitas, risiko bisnis,struktur aktiva dan ukuran perusahaan sebesar 90,32\%.Sedangkan sisanya (100\%-90.32\%) atau sebesar 9,68\% dijelaskan oleh variabel diluar model. Uji $\mathrm{F}$ statistik digunakan untuk memvalidasi model secara keseluruhan. Berdasarkan tabel 9 nilai probabilitas (F statistik0 sebesar 0,0000 $(<0,05)$ maka model mampu memvalidasi variabel dependen struktur modal.

Uji Hipotesis (Uji t Statistik) 
Wacana Ekonomi (Jurnal Ekonomi Bisnis dan Akuntansi), 20 (2) 2021, 155

Ukuran Perusahan Sebagai Variabel Kontrol Dalam Determinan Struktur Modal Manufaktur

\begin{tabular}{|c|c|c|c|c|}
\hline \multicolumn{5}{|c|}{$\begin{array}{c}\text { Tabel 10 } \\
\text { Hasil pengujian Hipotesis }\end{array}$} \\
\hline Variable & Coefficient & Std. Error & t-Statistic & Prob. \\
\hline $\mathrm{C}$ & 22.41198 & 704.1841 & 0.031827 & 0.9750 \\
\hline $\mathrm{X} 1$ & -0.372447 & 0.254616 & -1.462779 & 0.1629 \\
\hline $\mathrm{X} 2$ & 4.412901 & 2.986196 & 1.477767 & 0.1589 \\
\hline $\mathrm{X} 3$ & 0.138505 & 0.070933 & 1.952613 & 0.0486 \\
\hline $\mathrm{K}$ & -0.175511 & 27.31777 & -0.006425 & 0.9950 \\
\hline \multicolumn{5}{|c|}{ Effects Specification } \\
\hline \multicolumn{5}{|c|}{ Cross-section fixed (dummy variables) } \\
\hline Root MSE & 4.759204 & R-squared & & 0.935445 \\
\hline Mean dependent var & 41.78457 & Adjusted R-squared & & 0.903167 \\
\hline S.D. dependent var & 19.11761 & S.E. of regression & & 5.949006 \\
\hline Akaike info criterion & 6.678038 & Sum squared resid & & 566.2507 \\
\hline Schwarz criterion & 7.116833 & Log likelihood & & -74.47548 \\
\hline Hannan-Quinn criter. & 6.799741 & F-statistic & & 28.98129 \\
\hline Durbin-Watson stat & 2.131904 & Prob(F-statistic) & & 0.000000 \\
\hline
\end{tabular}

Pengujian secara parsial ini dilakukan dengan cara membandingkan tingkat signifikansi variabel independen dengan standar yang ditetapkan 5\% $(0,05)$. Berdasarkan Tabel 10 uji statistik $\mathrm{t}$ dapat dilihat nilai probabilitas variabel profitabilitas (X1) sebesar $0,1629(>0,05)$ dengan nilai koefisien -0,372447 (negatif) maka dapat diberikan interpretasi bahwa profitabilitas (X1) berpengaruh tidak signifikan negatif terhadap struktur modal (Y). Jadi dengan demikian hipotesis pertama (H1) belum dapat diterima (ditolak)

Nilai probabilitas variabel risiko bisnis (X2) sebesar $0,1589(>0,05)$ dengan nilai koefisien 4,412901 (positif) maka dapat diberikan interpretasi bahwa risiko bisnis (X2) berpengaruh tidak signifikan positif terhadap struktur modal (Y). Jadi dengan demikian hipotesis kedua (H2) belum dapat diterima (ditolak). Nilai probabilitas variabel struktur aktiva (X3) sebesar 0,0486 $(<0,05)$ dengan nilai koefisien 0,138505 (positif) maka dapat diberikan interpretasi bahwa struktur aktiva (X3) berpengaruh signifikan positif terhadap struktur modal (Y). Jadi dengan demikian hipotesis ketiga (H3) dapat diterima (teruji). Nilai probabilitas variabel ukuran perusahaan (X4) sebesar 0,9950 $(>0,05)$ dengan nilai koefisien $-0,175511$ (negatif) maka dapat diberikan interpretasi bahwa ukuran perusahaan (X4) berpengaruh tidak signifikan negatif terhadap struktur modal (Y). Jadi dengan demikian hipotesis keempat (H4) belum dapat diterima (ditolak).

Perbandingan hasil pengujian dengan dan tanpa variabel kontrol

Sesuai dengan konsep yang ada , bahwa variabel kontrol bisa merupakan bagian dari variabel independen yang dimasukkan dalam model ini.Ukuran perusahaan sebagai variabel kontrol dalam model yang diangkat atas dasar kajian teoritis yang jelas.

Tabel 11

Hasil pengujian dengan dan tanpa variabel kontrol

\begin{tabular}{cccc}
\hline No & Hasil Analisis & $\begin{array}{c}\text { Dengan variabel kontrol dalam } \\
\text { model }\end{array}$ & $\begin{array}{c}\text { Tanpa variabel kontrol dalam } \\
\text { model }\end{array}$ \\
\hline 1 & Adjusted R_Squared & 0,903167 & 0,908863 \\
2 & Uji F Statistik & 0,00000 & 0,00000 \\
3 & Profitabilitas & $-0,372447$ & $-0,372625$ \\
& (hipotesis ditolak) & 4,412901 & (hipotesis ditolak) \\
& (hipotesis ditolak) & 4,429632 \\
4 & Risiko Bisnis & 0,138505 & (hipotesis diterima) \\
& & (hipotesis diterima) & 0,138348 \\
5 & Struktur Aktiva & $-0,175511$ & (hipotesis diterima) \\
6 & Ukuran Perusahaan & - \\
\hline
\end{tabular}


Wacana Ekonomi (Jurnal Ekonomi Bisnis dan Akuntansi), 20 (2) 2021, 156

Ukuran Perusahan Sebagai Variabel Kontrol Dalam Determinan Struktur Modal Manufaktur

\section{Pembahasan}

Berdasarkan hasil penelitian khususnya uji hipotesis, maka dapat dibuat suatu pembahasan sebagai berikut.

Pengaruh Profitabilitas terhadap Struktur Modal

Hipotesis pertama yang menyatakan profitabilitas berpengaruh signifikan negatif terhadap struktur modal. Berdasarkan hasil uji statistik t nilai probabilitas variabel profitabilitas (X1) sebesar $0,1629(>0,05)$ dengan nilai koefisien $-0,372447$ (negatif) maka dapat diberikan interpretasi bahwa profitabilitas (X1) berpengaruh tidak signifikan negatif terhadap struktur modal (Y). Jadi dengan demikian hipotesis pertama (H1) belum dapat diterima (ditolak). Penelitian ini mendukung hasil riset yang didapatkan oleh Ahmed Sheikh \& Wang, (2011),(Mukhibad et al., (2020) yang menemukan profitabilitas berpengaruh tidak signifikan negatif terhadap struktur modal.Disisi lain hasil studi ini belum mendukung temuan Wardita \& Astakoni, (2018), Thippayana, (2014),Utami, (2019),Kaliman \& Wibowo, (2017),Handayani \& Darma, (2018),Joni \& Lina, (2010),Rahma, Muslim, \& Nalurita, (2019),Çitak \& Ersoy, (2012) yang mendapatkan profitabilitas berpengaruh signifikan negatif terhadap struktur modal. Hasil studi ini nampaknya sesuai dengan konsep Teori Pecking-Order (POT) yang menjelaskan perusahaan dengan profitabilitas yang lebih besar memiliki ratio hutang yang lebih kecil (Alipour et al., 2015), hanya saja hasil studi ini belum dapat digeneralisasi.

Pengaruh Risiko Bisnis terhadap Struktur Modal

Hipotesis kedua yang menyatakan risiko bisnis berpengaruh signifikan negatif terhadap struktur modal. Berdasarkan uji t nilai probabilitas variabel risiko bisnis (X2) sebesar 0,1589 $(>0,05)$ dengan nilai koefisien 4,412901 (positif) maka dapat diberikan interpretasi bahwa risiko bisnis (X2) berpengaruh tidak signifikan positif terhadap struktur modal $(\mathrm{Y})$. Jadi dengan demikian hipotesis kedua (H2) belum dapat diterima (ditolak). Hasil penelitian ini mendukung hasil riset yang didapatkan oleh Ahmed Sheikh \& Wang, (2011),(Mukhibad et al., (2020) yang menemukan risiko bisnis berpengaruh tidak signifikan negatif terhadap struktur modal. Sedangkan disisi lain studi ini belum mendukung temuan Kaliman \& Wibowo, (2017),Utami, (2019) yang menunjukkan bahwa risiko bisnis berpengaruh negatif dan signifikan terhadap struktur modal perusahaan. Hasil studi ini sejalan dengan pernyataan yang menjelaskan perusahaan dengan risiko bisnis yang tinggi seharusnya menggunakan utang yang lebih sedikit untuk menghindari risiko kebangkrutan (Brigham \& Huuston, $(2006,209)$. Mengingat risiko bisnis dapat berubah dari waktu ke waktu. Risiko bisnis berhubungan dengan jenis usaha yang dipilih dan kondisi ekonomi yang dihadapi.

\section{Pengaruh Struktur Aktiva terhadap Struktur Modal}

Hipotesis ketiga yang menyatakan struktur aktiva berpengaruh signifikan positif terhadap struktur modal. Berdasarkan uji t nilai probabilitas variabel struktur aktiva struktur aktiva (X3) sebesar $0,0486(<0,05)$ dengan nilai koefisien 0,138505 (positif) maka dapat diberikan interpretasi bahwa struktur aktiva (X3) berpengaruh signifikan positif terhadap struktur modal. Studi ini mendukung hasil riset (Jalil, 2018) yang menunjukkan bahwa struktur aktiva dapat dianggap sebagai variabel penjelas dari struktur modal pada sektor makanan dan minuman yang terdaftar di bursa efek Indonesia, Juga sejalan dengan yang didapat (Mas'ud, 2008), (Joni \& Lina, 2010), menemukan struktur aktiva berpengaruh sgnifikan positif terhadap struktur modal. Disisi lain hasil studi kali ini tidak sejalan dengan hasil riset (Astakoni \& Utami, 2019) yang mendapatkan struktur aktiva berpengaruh signifikan negatif terhadap struktur modal. Juga tidak sejalan dengan temuan Utami, (2019),Handayani \& Darma, (2018) yang mendapatkan struktur aktiva berpengaruh tidak signifikan negatif terhadap struktur modal. Hasil studi ini sejalan dengan pernyataan struktur aktiva adalah faktor yang mempengaruhi pembuatan keputusan struktur modal. Semakin besar struktur aktiva maka semakin besar penggunaan hutang pada struktur modalnya. Hal ini menunjukkan bahwa semakin banyak jumlah aktiva tetap yang bisa digunakan sebagai jaminan hutang oleh perusahaan (Riyanto, 2008,204)

\section{Pengaruh Ukuran Perusahaan terhadap Struktur Modal}

Hipotesis keempat yang menyatakan ukuran perusahaan berpengaruh signifikan negatif terhadap struktur modal. Nilai probabilitas variabel ukuran perusahaan (X4) sebesar 0,9950 $(>0,05)$ dengan nilai koefisien -0,175511 (negatif) maka dapat diberikan interpretasi bahwa ukuran 
perusahaan (X4) berpengaruh tidak signifikan negatif terhadap struktur modal. Hasil penelitian ini mendukung temuan yang didapat oleh Utami, (2019) dimana ukuran perusahaan berpengaruh tidak signifikan negatif terhadap struktur modal. Sementara hasil riset kali ini belum sejalan dengan temuan yang menyatakan ukuran perusahaan berpengaruh signifikan positif terhadap struktur modal (Astakoni \& Utami, 2019),(Wardita \& Astakoni, 2018),(Thippayana, 2014),(Kaliman \& Wibowo, 2017),(Wiagustini \& Pertamawati, 2015),(Handayani \& Darma, 2018). Perusahaan besar (large firm) memiliki free cash flow yang tinggi, sehingga bila memerlukan tambahan dana untuk membiayai investasi baru, maka perusahaan tersebut akan menggunakan sumber pendanaan yang murah yaitu sumber pendanaan dari dalam yang berupa retained earning. Seandainya sumber pendanaan dari dalam perusahaan, tidak mencukupi, perusahaan akan beralih pada sumber pendanaan dari luar yang berasal dari hutang daripada penerbitan saham baru (Riyanto, 2008,207)

\section{SIMPULAN}

Berdasarkan uji model baik uji determinasi maupun uji F statistik, didapat hasil yang sangat baik. Hipotesis pertama yang menyatakan profitabilitas berpengaruh signifikan negatif terhadap struktur modal belum dapat diterima (ditolak). Hipotesis kedua yang menyatakan risiko bisnis berpengaruh signifikan negatif terhadap struktur modal belum dapat diterima (ditolak). Hipotesis ketiga yang menyatakan struktur aktiva berpengaruh signifikan positif terhadap struktur modal dapat diterima. Hasil perbandingan pengujian dengan melibatkan variabel kontrol ukuran perusahaan, dapat dijelaskan bahwa model lebih baik tanpa variabel kontrol karena hasilnya bersifat menekan atau melemahkan model yang diangkat.

Secara praktis bagi perusahaan sampel dapat disarankan untuk membenahi tingkat profitabilitasnya, mengingat beberapa perusahaan memiliki profitabilitas yang negatif. Secara teoritis, meningkatkan jumlah sampel penelitian mengingat aplikasi eviews memerlukan data cross section yang lebih banyak sejalan dengan penambahan variabel independen, agar hasil analisis lebih baik. Kemudian perlu mengangkat model lain, dengan memasukkan variabel yang sifatnya makro ekonomi.

\section{DAFTAR PUSTAKA}

Ahmed Sheikh, N., \& Wang, Z. (2011). Determinants of capital structure: An empirical study of firms in manufacturing industry of Pakistan. Managerial Finance, 37(2), 117-133. https:// doi.org/10.1108/03074351111103668

Alipour, M., Mohammadi, M. F. S., \& Derakhshan, H. (2015). Determinants of capital structure: An empirical study of firms in Iran. International Journal of Law and Management, 57(1), 53-83. https:// doi.org/10.1108/IJLMA-01-2013-0004

Astakoni, I. M. P., \& Mariani, N. L. M. (2018). Profitabilitas, Pertumbuhan Perusahaan Dan Ukuran Perusahaan Sebagai Determinan Struktur Modal. KRISNA: Kumpulan Riset Akuntansi, 9(2), 20. https://doi.org/10.22225/kr.9.2.468.20-32

Astakoni, I. M. P., \& Nursiani, N. P. (2020). Efek Intervening Struktur Modal Pada Pengaruh Ukuran Perusahaan Terhadap Profitabilitas. Krisna Kumpulan Riset Akuntansi, 11(2), 137-147. https:// doi.org/10.22225/kr.11.2.\%25y.137-147

Astakoni, I. M. P., \& Wardita, I. W. (2020). Keputusan Investasi, Leverage, Profitabilitas, dan Ukuran Perusahaan Sebagai Faktor Penentu Nilai Perusahaan Manufaktur. Wacana Ekonomi (Jurnal Ekonomi,Bisnis Dan Akuntansi), 19(1), 10-23. https://doi.org/10.22225/we.19.1.1576.10-23

Astakoni, P. I. M., \& Utami, S. N. M. (2019). Determinan Struktur Modal Perusahaan ( Studi Pada Perusahaan Manufaktur Sub - Sektor Kosmetik \& Keperluan Rumah Tangga Yang Terdaftar Di Bursa Efek Indonesia Periode 2010 - 2016 ). Wacana Ekonomi (Jurnal Ekonomi,Bisnis Dan Akuntansi), 18(1), 1-16. https://doi.org/10.22225/we.18.1.987.1-16

Atinc, G., Simmering, M. J., \& Kroll, M. J. (2012). Control variable use and reporting in macro and micro 
Wacana Ekonomi (Jurnal Ekonomi Bisnis dan Akuntansi), 20 (2) 2021, 158

Ukuran Perusahan Sebagai Variabel Kontrol Dalam Determinan Struktur Modal Manufaktur

management research. Organizational Research Methods, 15(1), 57-74. https:// doi.org/10.1177/1094428110397773

Bawono, A., \& Shina, A. F. I. (2018). Ekonometrika Terapan Untuk Ekonomi dan Bisnis Islam Aplikasi dengan Eviews. Salatiga: Lembaga Penelitian dan Pengabdian Kepada Masyarakat (LP2M) IAIN Salatiga.

Brigham, E F, dan Houston, J. F. (2010). Dasar-Dasar Manajemen Keuangan (Kesepuluh). Jakarta $\bigvee$ Penerbit Salemba Empat.

Brigham, E. ., \& Huuston, J. . (2006). Dasar- Dasar Manajemen Keuangan. Terjemahkan Ali Akbar Yulianto. Jakarta: Salemba Empat.

Carlson, K. D., \& Wu, J. (2012). The Illusion of Statistical Control: Control Variable Practice in Management Research. Organizational Research Methods, 15(3), 413-435. https:// doi.org/10.1177/1094428111428817

Chen, J., Jiang, C., \& Lin, Y. (2014). What determine firms' capital structure in China? Managerial Finance, 40 (10), 1024-1039. https://doi.org/10.1108/MF-06-2013-0163

Çitak, L., \& Ersoy, E. (2012). The determinants of corporate debt ratio: An empirical analysis on Turkish corporations. International Research Journal of Finance and Economics, 95(January 2011), 151-162.

Dachlan, U. (2014). Panduan Lengkap Structural Equation Modeling Tingkat Dasar (Metodologi, Konsepsi, Aplikasi dengan Amos) (Pertama). Semarang: Lentera Ilmu.

Ferdinand, A. (2011). Metode Penelitian Manajemen (Pedoman Penelitian Untuk Penulisan Skripsi,Tesis dan Disertasi Ilmu Manajemen) (3rd ed.). Semarang: BP Undip Press.

Ghozali, I., \& Ratmono, D. (2014). Analisis Multivariat Dan Ekonometrika (Teori , Konsep, dan Aplikasi Dengan Eviews 10) (2nd ed.). Semarang: Undip Semarang.

Handayani, K. A. T., \& Darma, G. S. (2018). Firm Size, Business Risk, Asset Structure, Profitability, and Capital Structure. Jurnal Manajemen Dan Bisnis, 15(2), 48-57.

Harahap, S. . (2007). Analisis Kritis Atas Laporan Keuangan. Jakarta: PT Raja Grafindo Persada.

Harsono, M. (2002). Prosedur Pengujian Variabel Kontrol Dan Moderator Dalam Penelitian Perilaku Dengan Menggunakan Spss 10.00*). Seminar Bulanan Jurusan Manajemen Fakultas Ekonomi Universitas Sebelas Maret, pp. 1-7.

Hartoyo, A. K. W., Khafid, M., \& Agustina, L. (2014). Faktor Faktor Yang Mempengaruhi Struktur Modal Perusahaan Tekstil dan Garmen di Bursa Efek Indonesia. Accounting Analysis Journal, 3(4), 457465. Retrieved from http://journal.unnes.ac.id/sju/index.php/aaj\%0A

Hery. (2016). Analisis Laporan Keuangan (Adipramono, ed.). Jakarta: PT Grasindo.

Indriantoro, N., \& Supomo, B. (2009). Metodologi Penelitian Bisnis Untuk Akuntansi \& Manajemen (Pertama). Yogyakarta: Badan Penerbit Fakultas Ekonomi (BPFE).

Jalil, M. (2018). Pengaruh Risiko Bisnis dan Struktur Aktiva Terhadap Struktur Modal Pada Perusahaan Yang Terdaftar di BEI. Jurnal Akuntansi Dan Keuangan, 9(2), 1-10. Retrieved from https:// ejournal.unisi.ac.id/index.php/jak/article/view/453

Joni, \& Lina. (2010). Faktor-Faktor Yang Mempengaruhi Struktur Modal. Jurnal Bisnis Dan A kuntansi, 12(2), 81-96. https://doi.org/10.34208/jba.v12i2.187

Kaliman, R., \& Wibowo, S. (2017). Pengaruh Ukuran Perusahaan, Risiko Bisnis,Growth,Profitabilitas, Likuiditas Dan Sales Growth Terhadap Struktur Modal Pada Sektor Farmasi Yang Terdaftar Di BEI. Jurnal Bisnis Dan Akuntansi, 19(1a), 185-190. https://doi.org/10.34208/jba.v19i1a-3.284

Karina, F. (2015). Determinan Profitabilitas Pada Perusahaan Properti Dan Real Estate Go Public Di Indonesia. Univ Negeri Semarang. 
Wacana Ekonomi (Jurnal Ekonomi Bisnis dan Akuntansi), 20 (2) 2021, 159

Ukuran Perusahan Sebagai Variabel Kontrol Dalam Determinan Struktur Modal Manufaktur

Kuncoro, M. (2001). Metode Kuantitatif (Teori Dan Aplikasi Untuk Bisnis Dan Ekonomi) (Pertama). Yogyakarta: Unit Penerbit dan Percetakan AMP YKPN.

Mahanani, R. M., \& Asandimitra, N. (2017). Pengaruh Nilai Tukar, Suku Bunga, Inflasi, Gdp Dan Corporate Tax Rate Terhadap Struktur Modal Perusahaan Sektor Infrastruktur, Utilitas Dan Transportasi Yang Terdaftar Di Bursa Efek Indonesia Tahun 2011-2015. Jurnal Ilmu Manajemen (JIM), 5(3), 1-11.

Mahardika, E. S. S., Khafid, M., \& Agustina, L. (2014). Pengaruh Struktur Kepemilikan, Ukuran Dan Umur Perusahaan Terhadap Kinerja Intellectual Capital. Accounting Analysis Journal, 3(1), 100-108. https://doi.org/10.15294/aaj.v3i1.4192

Mas'ud, M. (2008). Analisis Faktor-Faktor Yang Mempengaruhi Struktur Modal Dan Hubungannya Terhadap Nilai Perusahaan. Manajemen Dan Bisnis, 7(7), 69-83.

Mukhibad, H., Subowo, S., Maharin, D. O., \& Mukhtar, S. (2020). Determinants of debt policy for public companies in Indonesia. Journal of A sian Finance, Economics and Business, 7(6), 29-37. https:// doi.org/10.13106/JAFEB.2020.VOL7.NO6.029

Rahma, A., Muslim, A., \& Nalurita, F. (2019). Pengaruh Profitabilitas, Likuiditas, Umur Perusahaan, Ukuran Perusahaan Dan Risiko Bisnis Terhadap Struktur Modal Pada Perusahaan Makanan, Minuman Dan Tembakau Bursa Efek Indonesia Periode 2012 - 2017. Prosiding Seminar Nasional Cendekiawan, 5 (2), 1-8. https://doi.org/10.25105/semnas.v0i0.5851

Rahmawati, A. P. (2019). Analisis Faktor Faktor Yang Mempengaruhi Struktur Modal (Studi Pada Perusahaan Pertambangan Yang Terdaftar Di Bursa Efek Indonesia Tahun 2012-2017). Tesis Universitas Muhammadiyah Magelang.

Rimbawan, D. (2013). Statistik Inferensial Untuk Ekonomi dan Bisnis (Teguh, Ed.). Denpasar: Udayana University Press.

Riyanto, B. (2008). Dasar-dasar Pembelanjaan Perusahaan. Yogyakarta: Badan Penerbit Fakultas Ekonomi (BPFE).

S, S., \& Machali, M. (2017). The Effect of Asset Structure and Firm Size on Firm Value with Capital Structure as Intervening Variable. Journal of Business \& Financial Affairs, 6(4), 1-5. https:// doi.org/10.4172/2167-0234.1000298

Seftianne, and H. R. (2011). Faktor Faktor Yang Mempengaruhi Struktur Modal Pada Perusahaan Publik Sektor Manufaktur. Jurnal Bisnis Dan Akuntansi, 3(2), 152-171. https://doi.org/10.34208/ jba.v13i1.214

Silaban, C. N., \& Pengestuti, I. R. D. (2017). Analisis Faktor-faktor yang Mempengaruhi Kebijakan Dividen dengan Firm Size sebagai Variabel Kontrol (Studi pada Perusahaan Manufaktur yang Terdaftar di BEI Tahun 2011- 2015). Diponegoro Journal of Management, 6(3), 1-15.

Sudana, I. M. (202AD). Manajemen Keuangan perusahaan Teori dan Praktik. Surabaya: Gelora Aksara Pratama.

Sugiyono. (2021). Teknik Sampling Dan Pengembangan Instrumen, (Materi Workshop Beeru Institut Dalam Profesor Talk Indonesia, 21 Februari 2021). Semarang.

Sumarni, M., \& Wahyuni, S. (2005). Metodologi Penelitian Bisnis (O. H. Sudiarto, Ed.). Yogyakarta: Andi.

Supranto, J. (2008). Statistik Teori Dan Aplikasi (Ketujuh; D. Barnadi \& W. Hardani, Eds.). Jakarta: Penerbit Erlangga.

Syamsudin, L. (2004). Manajemen Keuangan Perusahaan. Jakarta: PT Raja Grafindo Persada.

Tansyawati, F., \& Asyik, N. F. (2015). Pengaruh Profitabilitas, Pertumbuhan Aset Dan Risiko Bisnis Terhadap Struktur Modal. Jurnal Ilmu \& Riset A kuntansi Vol., 4(4), 683-694.

Thippayana, P. (2014). Determinants of Capital Structure in Thailand. Procedia - Social and Behavioral Sciences, 143, 1074-1077. https://doi.org/10.1016/j.sbspro.2014.07.558 
Wacana Ekonomi (Jurnal Ekonomi Bisnis dan Akuntansi), 20 (2) 2021, 160

Ukuran Perusahan Sebagai Variabel Kontrol Dalam Determinan Struktur Modal Manufaktur

Utami, E. S. (2019). Analysis Capital Structure on Indonesia Stock Exchange. Advance In Economics, Business and Management Research, 100(Icoi), 686-690. https://doi.org/10.2991/icoi-19.2019.120

Wardita, W., \& Astakoni, P. I. made. (2018). Profitabilitas, Pertumbuhan Perusahaan Dan Ukuran Perusahaan Sebagai Determinan Struktur Modal. KRISNA: Kumpulan Riset Akuntansi, 9(2), 20. https:// doi.org/10.22225/kr.9.2.468.20-32

Wiagustini, N. L. P., \& Pertamawati, N. P. (2015). Pengaruh Risiko Bisnis dan Ukuran Perusahaan pada Struktur Modal dan Nilai perusahaan pada Perusahaan Farmasi di Bursa Efek Indonesia. Jurnal Manajemen, Strategi Bisnis Dan Kewirausahaan Universitas Udayana, 9(2), 112-122.

Widianingsih, D. (2018). Kepemilikan Manajerial, Kepemilikan Institusional, Komisaris Independen, serta Komite Audit pada Nilai Perusahaan dengan Pengungkapan CSR sebagai Variabel Moderating dan Firm Size sebagai Variabel Kontrol. Jurnal Akuntansi Dan Pajak, 19(1), 38. https:// doi.org/10.29040/jap.v19i1.196

Yuliana Ria Savitri, N. P., \& Vivi Lestari, N. P. (2015). Pengaruh Risiko Bisnis, Ukuran Perusahaan Dan Pertumbuhan Penjualan Terhadap Struktur Modal. E-Jurnal Manajemen Unud, 4(5), 1238-1251. 